\title{
Genetic Engineering and Sustainable Crop Disease Management: Opportunities for Case-by-Case Decision-Making
}

\author{
Paul Vincelli \\ Department of Plant Pathology, 207 Plant Science Building, College of Agriculture, Food and Environment, \\ University of Kentucky, Lexington, KY 40546, USA; pvincell@uky.edu \\ Academic Editor: Sean Clark \\ Received: 22 March 2016; Accepted: 13 May 2016; Published: 20 May 2016
}

\begin{abstract}
Genetic engineering (GE) offers an expanding array of strategies for enhancing disease resistance of crop plants in sustainable ways, including the potential for reduced pesticide usage. Certain GE applications involve transgenesis, in some cases creating a metabolic pathway novel to the GE crop. In other cases, only cisgenessis is employed. In yet other cases, engineered genetic changes can be so minimal as to be indistinguishable from natural mutations. Thus, GE crops vary substantially and should be evaluated for risks, benefits, and social considerations on a case-by-case basis. Deployment of GE traits should be with an eye towards long-term sustainability; several options are discussed. Selected risks and concerns of GE are also considered, along with genome editing, a technology that greatly expands the capacity of molecular biologists to make more precise and targeted genetic edits. While GE is merely a suite of tools to supplement other breeding techniques, if wisely used, certain GE tools and applications can contribute to sustainability goals.
\end{abstract}

Keywords: biotechnology; GMO (genetically modified organism)

\section{Introduction and Background}

Disease management practices can contribute to sustainability by protecting crop yields, maintaining and improving profitability for crop producers, reducing losses along the distribution chain, and reducing the negative environmental impacts of diseases and their management. Crop disease management supports sustainability goals through contributions to food security, food safety, and food sovereignty for producers and consumers alike [1].

While pesticides have done much to contribute to food security and food sovereignty for many millions of people worldwide, pest and disease control through the regular use of pesticides is neither desirable nor sustainable over the long term. Pesticide use raises significant concerns over impacts on health [2-7] and the environment [8-12]. Furthermore, we cannot address the challenges to sustainability posed by synthetic pesticides by simply switching to the application of natural pesticides, because the same concerns apply to them [12-19].

Practices for managing crop diseases fall into four general categories: host plant resistance, cultural practices, biological control, and chemical control. If pesticide use is to be reduced, it will be necessary to depend more on the remaining three approaches. Cultural practices (examples include crop rotation, polyculture, manipulation of planting date, etc.) certainly play a central role in disease management [20]. However, control achieved via cultural practices is sometimes inadequate, impractical, or economically nonviable. Natural biological control of plant pathogens is a fact of life, as it undoubtedly occurs at some level in all agricultural soils. However, there are many destructive diseases for which years of research have failed to lead to practical, commercially viable biocontrol options. Thus, in order to reduce the need for pesticides while still attaining acceptable yields, it will be 
critical to judiciously take full advantage of plant genetics. After all, if farmers are to reduce pesticide use, they must have viable alternatives for controlling diseases.

Host plant resistance is an ecologically sound way to manage crop diseases. Approaches to genetic crop improvement span an ever-expanding range of techniques, from simple phenotypic selection through techniques of genome editing (discussed below). Conventional breeding can often produce adequate levels of disease control, and we can expect that all breeding techniques will continue to play important roles indefinitely. However, when conventional breeding and other management options are inadequate, or when linkage drag limits the usefulness of conventionally derived traits, GE offers alternatives. As examples of diseases for which GE presently appears to represent the only acceptable disease management in culturally or economically important crops, consider papaya ring spot in Hawaii [21], cassava brown streak disease in Africa [22], and citrus greening in Florida [23-25]. The loss of important crops to infectious diseases is completely contrary to the principles of sustainability. Thus GE can make it possible to save crops in the face of virulent disease epidemics, crops that may be integral to food security, sources of farmer income, or culturally important dietary components. In addition, GE can make it possible to reduce farmers' dependence on pest-control products, with undeniable benefits for sustainability. The deployment of Cry proteins for insect control serves as an excellent example of how a GE approach can contribute to sustainability through reduced application of pesticides, resulting in fewer pesticide poisonings, increased biodiversity, and increased biocontrol services [26-35]. Certainly other examples seem eminently possible as we employ additional GE traits for pest and disease control. One must also acknowledge that Cry proteins serve as an example of how overreliance on single genetic traits can allow for pest evolution to overcome such a trait [36-39]. In fact, this presents another justification for taking full advantage of the opportunities offered by GE. Selection pressure towards virulence is a "given" whenever managing pests and diseases. Breeders therefore need a wide array of genetic options in order to diversify the arsenal of resistance traits deployed in crops, thereby reducing this selection pressure. As will be apparent in this review, GE is greatly expanding the genetic options for disease control available to breeders.

\section{Strategies for Engineering Resistance}

There is a wide variety of published GE strategies for engineering disease resistance, and ongoing research and expanding genetic resources [40] are likely to lead to additional strategies. Furthermore, within most of those strategies, diverse applications are conceivable. Taken together, these suggest that GE presents a vast pool of genetic possibilities for future generations. This will allow breeding for disease resistance to remain highly dynamic in the face of pathogen adaptation towards virulence on resistant cultivars.

In contrast to typical pesticides, GE mechanisms are often designed to have selective efficacy against particular target pathogens. High target selectivity is advantageous, in that it minimizes health concerns for consumers as well as risks to non-target biota in and around agroecosystems. However, the drawback is that one GE trait is unlikely to protect against the full spectrum of damaging pathogens on a given crop-which is also true of many conventional genes for disease resistance.

While it is difficult to foretell which GE strategies will have the greatest impact on crop disease control in the coming decades, all those described below hold promise and, in the author's opinion, merit continued research attention. Some have demonstrated proof-of-concept, while others have been evaluated in the field and, in certain cases, introgressed into commercially viable varieties. All strategies described below take advantage of -and in most cases, mimic — processes that occur in Nature.

\subsection{Boosting Plant Recognition of Infection}

Plants have evolved to trigger basal defenses upon recognition of certain conserved molecules of an invading pathogen. These molecules, which are highly conserved evolutionarily and are metabolically important for the pathogen, are referred to as pathogen-associated molecular patterns 
(PAMPs) [41-43]. Receptor molecules in the host membrane recognize PAMPs and elicit a natural defense response called PAMP-tiggered immunity (PTI). PAMP receptor molecules differ among plant species. Thus, genes encoding PAMP receptors from crops and other plants can be transformed into other crops, expanding the range of pathogen molecules that trigger PTI in the latter [43]. A gene encoding a PAMP receptor does not introduce a novel defense mechanism into the plant. The transferred PAMP receptor merely allows the receiving plant to recognize infection, so it can respond with its own, natural immune system. Increased resistance has been obtained using this strategy against a range of bacterial diseases in both monocots and dicots [44-47].

An important question is whether the transfer of PAMP receptors among plant species would increase the risk of selection towards wider pathogen host ranges. Since PAMPs are highly conserved molecules that are metabolically important for the pathogen [44], rapid evolution of these molecules is unlikely. Rational deployment strategies, such as those described in Section 3, can also reduce this risk.

\subsection{Mining R Genes}

PTI places strong selection pressure on pathogens to restore a virulent host-parasite interaction. According to the prevailing model of disease resistance, pathogens produce one or more effector molecules which enhance virulence, resulting in effector-triggered susceptibility (ETS) [42,48,49]. Over evolutionary time scales, plants respond to ETS by producing an intracellular receptor ( $R$ protein) which detects the presence or activity of particular pathogen effectors, restoring a resistance response called effector-triggered immunity or effector-triggered defense [41,42,48,50]. In the face of a renewed defense response in the host, a pathogen may eventually evolve to produce a new effector to restore compatibility. In turn, the plant may evolve a new $R$ protein. This coevolutionary, gene-for-gene, "molecular arms race" $[48,50]$ between pathogen effectors and their corresponding $R$ proteins has yielded pools of $R$ genes (resistance genes) useful in breeding crops for disease resistance [42].

One way GE can contribute to resistance breeding is through cisgenics: engineering only with genetics obtained from a crop's sexually compatible gene pool [51]. Conventional breeding techniques are often suitable for introgressing cisgenes into new varieties, in which case GE is unnecessary. However, in some crops, such as potato, grape, banana, apple, and strawberry, conventional breeding is exceptionally difficult or time-consuming. For crops such as these, cisgenes can be transferred via GE [43,51,52], resulting in a genetic outcome that would be conceivable-although perhaps impractical-by conventional means. A major advantage of cisgenics over conventional breeding is that it circumvents linkage drag [43,51].

For some plants, hybridization is difficult or impossible using current techniques. In such cases, GE offers an alternative for introgressing $R$ genes, even from plants that are not part of a crop's normal breeding pool. For example, in tomato, bacterial leaf spot, a highly destructive disease, was controlled in the field with a single $R$ gene obtained from pepper [53,54]. Indeed, the level of control obtained was higher than that obtained by any conventional breeding approach. This $R$ gene is expected to provide an alternative to the repeated use of foliar copper applications, benefiting both field workers and the environment [54]. Other examples of "mining" of $R$ genes from related as well as unrelated plant species have been published for both monocots and dicots $[47,55,56]$. Recent research has also shown that it is possible to enhance disease resistance by modifying the target of a pathogen effector so that it recognizes other pathogen effectors [57]. For example, the target molecule of pathogen effector " $\mathrm{A}$ " can be modified (with modest edits) so that its product is activated (and thereby triggers a defense reaction) by another pathogen's effector "B." This creative approach provides new disease resistance traits while avoiding any transfer of genetic material. Durability of $R$ genes could be enhanced by engineering resistance based on recognition of effectors critical to pathogenicity [57].

It is worth recalling that $R$ genes do not code for new biochemical pathways; they merely code for receptor molecules. This allows the plant to recognize the presence of an invading pathogen, thereby taking advantage of their native, natural mechanisms of disease resistance. 
Resistance conferred by individual $R$ genes is often not durable, because widespread deployment of an $R$ genes selects for pathogen strains capable of overcoming it [42,58-60]. The ability to "mine" $R$ genes from plants outside of a crop's breeding pool may be especially important for sustainability, in that it opens a vast pool of $R$ genes potentially useful for breeding.

\subsection{Upregulating Defense Pathways}

Molecules involved in defense signaling, defense regulation, or other processes can be upregulated, boosting general defense responses. Such defenses include generation of reactive oxygen species, callose deposition, synthesis of pathogenesis-related (PR) proteins, and increased activation of systemic acquired resistance (SAR) [23,61]. As with the previously described strategies, this strategy takes advantage of the plant's own natural immune system and does not introduce new metabolic pathways. This approach has been successful against bacterial pathogens attacking several host species [62-64], and it offers promising results for enhancing resistance to citrus greening [23], a disease of urgency for the citrus industry. Upregulation of defense pathways was also successful against destructive fungal pathogens, including Rhizoctonia solani (the cause of many diseases) and Magnaporthe oryzae (the cause of rice blast) [61,65]. In both cases, resistance was achieved by expressing a native rice gene under the control of a constitutive promotor from maize, introducing neither a novel pathway nor a non-crop gene. It may eventually be possible to upregulate defense responses using native cisgenic promotors, avoiding the use of any DNA outside of the crop's breeding pool.

\subsection{Disarming Host Susceptibility Genes}

Plants possess genes whose products are important in its normal physiology, but in some way also function to facilitate pathogen infection and colonization. These can be considered susceptibility genes [66]. (See the Supplemental Table 1 in [66] for a long list of examples.) Changes in such genes by natural means can result in increased disease resistance [47,67]. The same is true for GE-induced changes [66,68-70]. While we must remain aware that susceptibility genes may have pleiotropic effects, disarming susceptibility genes may hold promise for durable resistance for two reasons: first, in some pathosystems, many host factors contribute to host-parasite compatibility, offering many potential targets to disarm through very modest changes in DNA sequence; and second, overcoming a disarmed susceptibility gene requires the pathogen to gain a new function to replace the lost host factor it was exploiting. Gaining a new function is not likely to be easily accomplished [66]. Disarming susceptibility genes can be achieved without introducing a novel metabolic pathway or leaving exogenous DNA in the final product.

\subsection{Producing Antimicrobial Compounds}

Genes encoding antimicrobial compounds can be expressed in crop plants, resulting in restricted pathogen activity and, consequently, increased disease resistance. As a result of citrus greening, a highly destructive bacterial disease, the economic health and even survival of the Florida orange juice industry is uncertain [25,71]. Thus far, the only potentially viable, environmentally acceptable solution may be citrus trees that express antimicrobial peptides called defensins, produced by genes obtained from spinach $[25,72,73]$.

Resistance to diverse fungal diseases was obtained in grape and cotton when plants were transformed to constitutively produce chitin-degrading enzymes [74,75]. All of the diseases controlled in these studies were caused by fungi that contain chitin as an important component of their cell walls. The sources of the chitinase genes were Trichoderma species, fungal parasites of other fungi. Plants may be engineered to deliver pest-control substances that act in particular tissues or organs of multicellular, anatomically complex pathogens [76], which may have particular relevance to nematode control.

One advantage of transforming crops with genes for natural antimicrobial substances is that one can employ in-vitro techniques of molecular evolution to broaden the range of molecular targets 
of such antimicrobials [77]. Such techniques potentially can be employed to reverse the buildup of pathogen resistance to the antimicrobial.

Microorganisms could potentially serve as a source of many antimicrobial compounds, though public acceptance of transgenes from microorganisms is mixed [78]. In contrast to several strategies described in this review, this strategy does not take advantage of existing defense mechanisms; rather, it creates a new one.

\subsection{Silencing Essential Pathogen Genes}

The presence of double-stranded RNA (dsRNA) in the cytoplasm of eukaryotic cells triggers the natural and targeted process of post-transcriptional gene silencing (RNA silencing, RNA interference, or RNAi) [79]. Through the use of genetic constructs with sequence identity to important pathogen genes (and, ideally, with little to no identity to mammalian genes), RNAi can be elicited in plants to silence such genes, resulting in reduced disease. In RNAi, no novel protein or biochemical pathway is created in the crop; the natural process of RNAi is invoked in order to silence a particular target gene in the pathogen.

The papaya industry in Hawaii was saved by transforming papaya with the coat protein gene of papaya ringspot virus. This gene elicits RNAi against this highly destructive virus $[21,80]$. Such a GE application mimics cross-protection, a phenomenon in which symptoms due to severe strains of a virus can be reduced by prior infection by a mild strain. Cross-protection is a perfectly natural phenomenon. Unfortunately, implementing it for disease management has practical drawbacks [81], which is why transgenic coat-protein-mediated resistance was utilized against this devastating virus disease. While consumers may be hesitant to eat transgenic papaya containing a viral coat-protein gene, they may be surprised to know that they are eating complete virus particles in fruit harvested from non-transgenic, infected trees, including fruit from cross-protected trees. RNAi provides control of other destructive viruses of crops, including the viral complexes that attack cassava in East Africa [22,82], soybean [83], and summer squash [84], and others [47,85].

Recent research clearly highlights the substantial potential which RNA silencing offers for management of diseases caused by biotrophic fungi, necrotrophic fungi, and oomycetes [86-91]. These studies report partial to complete control of diseases caused by several of the most important pathogens worldwide. Likewise, gene silencing holds much promise for pesticide-free nematode management [92-94]. Diverse pathogenicity genes in nematodes present many molecular targets [95], highlighting the promise RNA silencing holds for sustainable, long-term nematode management.

Some success in RNAi-based insect control has been obtained by feeding insects dsRNA constructs that trigger RNAi [96,97]. Commercial products based on this technology are being pursued. Since foliar applications of small RNAs require no genetic changes in the plant, this technology may appeal to consumers for its "non-GMO" status. Of course, compared to genetic changes, there are sustainability costs (both economic and environmental) to the use of products that must be applied repeatedly and indefinitely.

\subsection{Modifying Host Targets of Pathogenicity/Virulence Factors}

Certain plant pathogens produce molecules (virulence factors) that play a role in virulence by binding to host target molecules [98]. The molecular targets of these in the crop can be engineered so as to result in reduced binding, thereby increasing disease resistance [99]. Genetic modification of targets of pathogen virulence factors increases host resistance without introducing an exogenous biochemical pathway into the plant, and also can be achieved without transgene insertion.

\subsection{Detoxifying Pathogen Toxins}

Pathogen-produced toxins can disrupt important biochemical processes of their hosts, thereby facilitating disease development [100]. In turn, plant resistance may be conferred by a host enzyme that inactivates a pathogen toxin, whether that enzyme is native [101] or the result of GE. As an example of 
the latter, the phytotoxin oxalic acid is central to pathogenicity of Cryphonectria parasitica, the cause of catastrophic epidemics of chestnut blight [102]. Significantly less disease development was observed in American chestnut trees transformed with a wheat gene coding for the production of the degradative enzyme, oxalate oxidase [103]. As another example, a toxin-degrading enzyme encoded by a barley gene was transformed into wheat, resulting in resistance in the wheat to the highly destructive disease, Fusarium head blight [104]. In both examples, the gene constructs used included a viral promotor and a bacterial selectable marker, so in their present configuration, these GE crops clearly qualify as transgenic. However, these potential concerns may be addressed by employing native promotors derived from the engineered crop and marker-free transformation [85].

\subsection{Engineering CRISPR/Cas Immune System}

CRISPR (Clustered Regularly Interspaced Short Palindromic Repeats) is a prokaryotic defense system that targets the DNA of invading viruses and plasmids [105,106]. In this system, an endonuclease (commonly CRISPR associated protein 9, abbreviated Cas9) is directed to cut the invading DNA at a particular target, where the DNA sequence matches the sequence of an RNA guide strand (gRNA) associated with Cas9. Plants can be transformed to produce both Cas9 and a target-specific gRNA, in order to cleave a specified target of invading DNA. For example, a Cas9/gRNA complex can be engineered to target the replicating DNA of Geminiviruses, which are highly destructive to crops in tropical and subtropical climates [106-109]. Such an engineered Cas9/gRNA complex produces a sequence-specific, targeted immune response which can result in significant host resistance against a DNA virus. These laboratory-based results are exciting if they are reproduced in the field, since conventional breeding has not been universally successful against Geminiviruses [108,110]. A variety of viral genetic elements can be successfully targeted $[106,108]$, which would confer long-term utility to this strategy. Crops engineered to express a CRISPR/Cas immune system are transgenic, containing DNA sequences which are bacterial and viral in origin (coding for Cas9 and gRNA, respectively), which may hamper public acceptance.

\subsection{Reducing Infection Courts}

Transgenic crops expressing $\delta$-endotoxins (Cry proteins) from Bacillus thuringiensis (Bt) have been used successfully to control certain insects. Another benefit from the use of Bt corn has been the well-documented reductions in mycotoxin contamination that sometimes occur. Reductions in both fumonisins and aflatoxins have been reported in field studies on several continents [111-115]. These reductions have been associated with reduced insect wounding on kernels expressing a Cry endotoxin, resulting in fewer openings for infection by mycotoxin-producing fungi $[114,116]$. The $\mathrm{Bt}$ trait is not a "silver bullet", eliminating all mycotoxin risk. However, reductions occur often enough that the Bt trait is commonly thought to contribute to food safety and livestock health. It is interesting to note that the application of synthetic insecticides to control kernel-feeding insects on non-Bt plants also sometimes reduces insect feeding and fumonisin contamination. However, to this observer, genetic approaches to reducing mycotoxin contamination are preferred for considerations of both environmental protection and consumer health.

\section{Deployment of GE Traits}

Just as pathogen populations adapt to conventionally bred resistance, prudence dictates that we anticipate the same in response to the deployment of engineered resistance mechanisms. Reducing disease pressure through integrated disease management remains an essential strategy for reducing selection pressure towards overcoming resistance traits [117]. Thus, GE traits should be deployed in conjunction with appropriate management practices for disease control. This will help to promote sustainability by extending the useful life of resistance traits. In addition, GE traits must be deployed with attention to genetic diversity. Widespread deployment of a single gene conferring high levels of disease resistance imposes substantial selection pressure for virulence, often resulting in pathogen 
strains highly virulent on plants possessing that resistance gene $[59,118,119]$. Thus, the widespread deployment of solo resistance genes-whether conventional or GE-derived-should not be expected to provide sustainable disease control.

One way to introduce genetic diversity is via "stacking" multiple, distinct resistance traits. Creating in planta diversity by gene stacking would be expected to increase the durability of resistance traits, since the target pathogen must overcome all genes in the stack to be fully virulent $[37,43,52,58,62,66,120-122]$. Stacking conventional $R$ genes with diverse biological effects on the pathogen has been shown to increase resistance durability [58]. This suggests that traits based on distinct GE strategies could also be stacked in order to disrupt the evolution of virulence. Depending on the crop, stacking via GE may often be more practical than by other breeding techniques [43]. Molecular tools also permit us to identify $R$ genes that correspond to "core," conserved pathogen effectors [47], which may impose a high fitness cost on virulent pathogen strains. High-throughput techniques for cloning R-genes [123,124] are expected to greatly expand the libraries of $R$ genes available to breeders. Plant artificial chromosomes [125] will likely facilitate stacking of numerous genes performing diverse functions, thus increasing the durability of deployed genes. Rotation of $R$ genes may also contribute to durability [126]. A long-term, sustainable approach to disease management may involve coordination of breeding programs to systematically substitute or rotate stacked genes at periodic intervals. Deploying diverse genetics through time in this way would further disrupt pathogen adaptation.

\section{Selected Concerns}

A variety of concerns are raised with respect to GE crops. In-depth consideration of all of these lies beyond the scope of this paper. However, several selected concerns are discussed below.

\subsection{Flow of Recombinant DNA}

Perhaps the most significant biological risk in the cultivation of GE crops is the possibility of transgene flow to non-GE crops or to wild or weedy relatives [127]. Flow of genes into wild or weedy relatives can occur also from conventionally bred, non-GE crops [128-130], even causing negative environmental consequences [131]. However, transgenesis may create a higher level of uncertainty in terms of environmental risk. In wild or weedy relatives, transgenes may have no net impact on fitness [132], or they may confer fitness costs [133], likely leading to a decline in frequency of the transgene over time. Alternatively, a transgene may confer a fitness advantage on the recipient species or population [134], which creates the possibility of long-term ecological impacts. Of course, if engineered genetics are cisgenes [43,51,52], ecological risks are no different than those that would result from conventional breeding.

Crop residues are sources of environmental DNA [135], including transgenic DNA. DNA from residues - transgenic or not - is potentially available for transformation of soil microorganisms via natural processes [136]. Such events are rare but possible [136-141]. For prevalent transgenes currently in use, the importance of such a risk is unclear, for several reasons: these genes are already widespread in the environment in their source organisms [137]; crop transgenes sometimes are designed with eukaryotic promotors rather than prokaryotic ones; and they may not be codon-optimized for a recipient microorganism. Certainly, assessing such risks would be facilitated by a better understanding of the potential selective impact of transgenes transformed into soil microorganisms [136,142].

Given the long-term uncertainties of uncontrolled dispersal of transgenes, particularly via pollen, mitigation of risk is critical. Several basic precautions can be taken, including spatial separation of GE and non-GE crops [143] and avoiding transgenic crops in areas where wild relatives occur. For plant species whose pollen is almost completely free of chloroplasts, transgenes in chloroplasts would reduce the risk of transmission [144], although the high transgene copy number in chloroplasts may be physiologically taxing on the plant. Breeders can take advantage of gametic incompatibility, 
which can block fertilization of non-GE corn kernels by GE pollen [145]. Additional options exist for mitigating the risk of transgene flow $[130,144,146,147]$. Since in some crops, the risk of transgene flow may be greatly minimized but remain non-zero, some may argue for GE to be limited to non-transgenic applications. Numerous non-transgenic approaches are described above in Section 2, and more can be expected with continuing research.

\subsection{Consumption of GE Crops}

All share a concern for producing safe, wholesome food. This is a fundamental requirement of the social pillar of sustainability. The weight of the evidence in favor of safety of crop improvement using GE is overwhelming, as reflected in the position statements of diverse, prestigious scientific societies [148-163]; scientific review papers [164-171], and hundreds of peer-reviewed research papers. This is not to suggest that there will never be a GE plant produced that has some unintended, negative effect on a consuming animal or human. No one can assure against such risk, whether the crop is conventional or GE. Rather, these facts support the notion, commonly held among scientists, that what matters to food safety is not the process used to create a plant, but the properties of the resulting plant $[157,172-175]$. In fact, instead of posing a routine food-safety risk, the reverse is true: GE traits can actually increase food safety as compared to conventional crops (see [176] and citations in [177]).

In pondering questions of food safety, two additional facts seem important:

(1) Recombinant DNA is a completely normal part of our diet. Our crops contain much natural recombinant DNA. Naturally produced recombinant DNA can result from: meiotic recombination; the action of diverse and often abundant mobile genetic elements; gene duplication; chromosomal inversions and translocations; novel gene assemblies; shuffling of exons and other gene fragments; chromosomal duplication; horizontal gene transfer; and incorporation of viral genes. In fact, all land plants appear to be "natural GMOs," as all contain genes apparently acquired horizontally [178-194]. To my knowledge, there is no published, validated research showing any fundamental biochemical or biophysical difference between DNA recombined in a test tube vs. that recombined in a living cell.

(2) Compared to other breeding techniques, targeted DNA manipulations achieved during transgenesis, cisgenesis, intragenesis, or genome editing are no more disruptive-and are commonly less disruptive - to a plant's genome, transcriptome, proteome, and composition than other methods of crop improvement [170,171,195-200]. If unanticipated health consequences from GE manipulations merit concern, so do the unanticipated health consequences of each new conventionally bred crop variety [201]. It does not matter that breeding through phenotypic selection is a technique that is thousands of years old-every plant is a unique genetic and epigenetic creation. Therefore, every new plant presents unknown risks as a result of its unique genetic and epigenetic heritage.

\subsection{Corporate Influence}

Consolidation of the seed industry has been substantial since the introduction of GE crops $[202,203]$. This consolidation raises concerns as to whether food-system challenges will be decided more based on corporate interests than by broader considerations of sustainability. Related to this are concerns over patenting of GE traits and the restrictions patenting places on farmers with respect to seed saving and sharing [204-206]. In the developing world, where the food security of many smallholders depends on saved or shared seed [207], such restrictions are an acute concern (Figure 1). However, such restrictions are not universal, and royalty-free distribution is certainly compatible with GE $[22,208,209]$. 


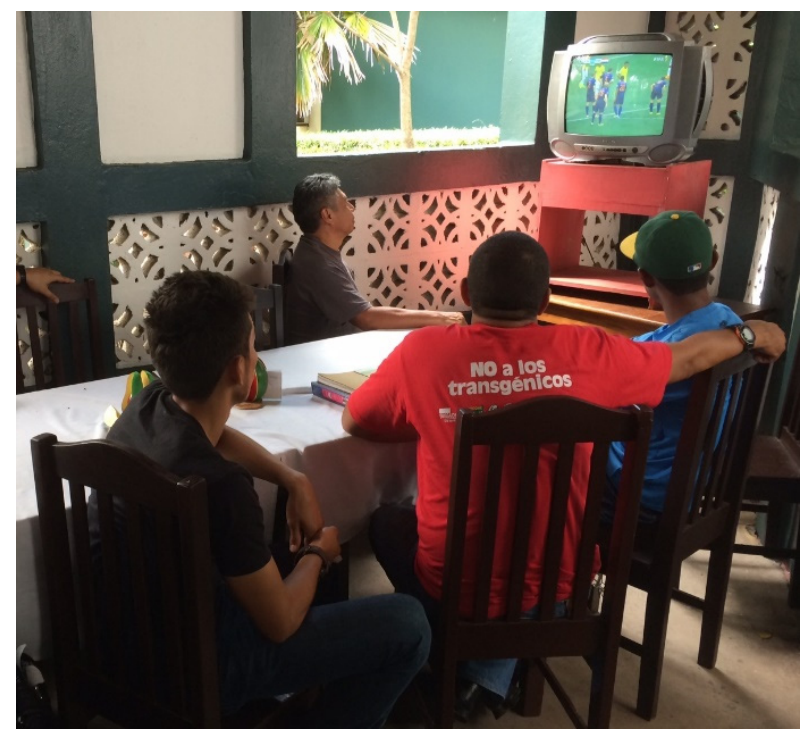

(a)

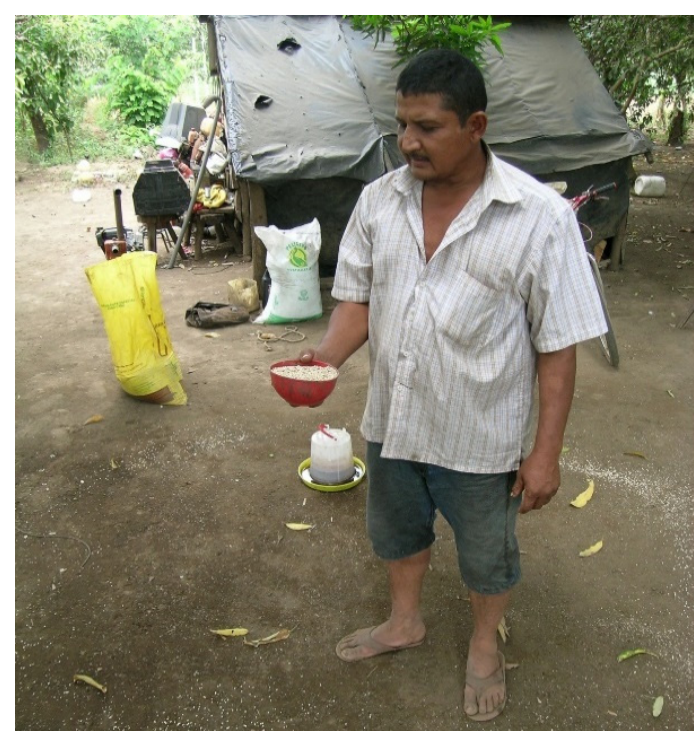

(b)

Figure 1. Selected perspectives on genetically engineered (GE) crops. (a) Some consider transgenic crops to be in conflict with their local culture; note the red t-shirt: "NO to transgenics." It is worth noting that some applications of GE do not employ transgenesis and therefore may be more widely acceptable. (b) Many smallholders are understandably concerned about the restrictions patents place on seed saving and sharing. In developing economies, GE traits in the public domain are likely to be the most accepted.

In the USA, GE traits and crops are protected under both the Plant Variety Protection Act and utility patents, the latter providing 20 years of protection against unauthorized use or distribution of the trait and/or genotype by farmers, plant breeders, and researchers [205,210-212]. Such patents protect the substantial investment in their development, and provide benefits that accrue through crop innovation. However, patent restrictions also pose risks to sustainability. Restrictions on the free movement of germplasm among breeders may create risks to the long-term diversity of crop genetics, and they can impede public crop improvement programs [210,213]. In addition, patent restrictions have at least the potential to constrain independent public research [211,214]. It is not surprising that utility patents are sought for GE traits because of their very high development costs, which can be well in excess of $\$ 100,000,000$ [215]. Seed companies have little incentive to develop and market crops that their competitors can also sell. However, it is significant that patent applications by major seed companies have not been limited to GE traits, as utility patent protection has also been sought for conventionally bred traits [213] and genotypes. The current legal landscape allowing protection of plant traits under utility patents was not created exclusively for GE crops. Rather, it is the result of a series of federal legislative acts and Supreme Court decisions beginning as early as 1930 [204,205]. Thus, even if a less aggressive patent landscape were desirable from a sustainability standpoint, a move away from such protections of intellectual property would likely require either a tectonic shift in market pressure from consumers in support of initiatives such as the Open Source Seed Initiative [216] or, literally, an act of Congress.

\subsection{Other Concerns}

Some express concern that GE crops promote large-scale agriculture, with an associated loss of agrobiodiversity. It is true that present-day GE crops are often suitable for large-scale farming. However, large-scale monoculture exists even in non-GE crops, as it is driven by economies of scale and not by GE. Furthermore, when GE traits are deployed in diverse germplasms, there appears to be little loss in the genetic base [210]. GE is simply a suite of crop-improvement tools, which can be applied to 
agriculture at any scale, depending on the particular circumstances. GE traits can be introgressed into an unlimited number of local varieties, thus preserving agrobiodiversity while allowing the benefits of GE traits to accrue to farmers, consumers, rural communities, and/or the environment [22,209,217]. Furthermore, large-scale crop production very likely will continue to play an essential role in food and fiber production for the billions of us who depend on farmers. Food-system challenges should not be framed as "either-or" situations. It is critical to work towards increasing the sustainability of all farming systems, including large-scale systems, and the selective and wise use of GE crops can be expected to contribute towards that goal at all scales of farming.

In some instances, populations may conclude that GE is incompatible with their local food culture. While this concern lies outside the realm of scientific data, scientists have an obligation to respect such concerns.

\section{Genome Editing: More Precise, Dynamic Tools for GE}

Biology is being revolutionized by genome editing based on CRISPR/Cas9 technologies. These technologies not only provide powerful tools for research and therapeutics; they provide new methods for engineering crops to address genuine human needs and environmental impacts of crop production. Until recently, most applications of GE in crops involved insertion of DNA from an evolutionarily distant organism via either the bacterium Agrobacterium tumefaciens (a "natural genetic engineer") or the "gene gun." In contrast to plant transformation, genome editing can produce defined genetic changes in targeted genes much like a word processor, and with high efficiency and limited off-target changes $[69,218-220]$. Furthermore, it can be done in ways that leave no trace in the plant of foreign DNA (such as antibiotic resistance genes, plasmid fragments, etc.) [221,222]. Several examples were cited in Section 2 of the successful application of CRISPR/Cas9 technologies in developing crop disease resistance [69,70,106-109], and many others are expected. Indeed, CRISPR/Cas9 technologies may facilitate the development of entirely novel GE strategies not presented in this review.

Genome editing permits a more dynamic range of possibilities for genetic changes beyond those provided by plant transformation. It has commonly used for targeted mutagenesis and targeted modification: making very modest changes in existing genes in live cells $[69,105,219,223,224]$. Genetic changes can be as limited as a single nucleotide change, with no trace of introduced DNA. Thus, through targeted mutagenesis via CRISPR-Cas9, it is possible to create a nontransgenic gene edit that cannot be distinguished from a mutation that was naturally occurring or that was introgressed by conventional breeding [221]. Many experts consider such gene edits as excludable from GMO regulation [225] and argue that they should be clearly distinguished from GMOs, referring to them as "genetically edited crops" (GECs) [224]. Through homology-directed repair (HDR), genome editing can be used to edit a crop's genome so as to contain a novel functional DNA string identical to that of any source organism, including unrelated ones $[223,226,227]$. One application of HDR-based genome editing could be to edit a gene so as to match a gene from a crop's natural gene pool (=cisgenesis). Genome editing may thus be able to expedite genetic outcomes achievable through conventional breeding. For example, cisgenic applications of genome editing may present a particularly important path to increased disease resistance in crops that are difficult to hybridize [43,51]. Alternatively, HDR-based genome editing could conceivably be used to add a gene sequence from some evolutionarily distant organism, which is the equivalent of transgenesis $[223,227]$ and therefore warranting regulatory scrutiny similar to that of transgenic crops [225].

Experienced molecular biologists commonly report that implementing CRISPR/Cas 9 techniques is relatively straightforward, efficient, and low-cost, as compared to other techniques of genome editing. Depending on the regulatory environment, some applications of genome editing could help to "democratize" GE making it more accessible to small seed companies, nonprofit organizations, and governments in developing countries. In addition, it may facilitate beneficial applications of GE beyond large-scale agronomic crops (corn, soy, cotton, etc.), which currently dominate GE acreage globally. 


\section{Conclusions}

The sustainability of food systems is a unifying interest that lies beyond particular crop production approaches or philosophies. The critical question is not, "Do certain GE strategies fit within a given production philosophy?" but rather, "Can a given practice or technology take us further down the path towards sustainability?" With respect to disease control, GE technologies, used wisely, certainly will permit the expeditious introduction into crops of targeted, diverse resistance mechanisms that mimic natural processes. While recognizing the important benefits GE technologies offer, larger considerations merit attention, especially questions of public acceptability and of whether there are any long-term ecological risks different from those posed by conventional breeding. In considering such issues, it is important to remember that, not only do diverse GE strategies exist, but diverse GE manipulations are possible, ranging from very modest, targeted mutagenesis, through cisgenics and intragenics, to insertion of transgenes from other crops, from other (non-crop) plants, and from evolutionarily distant organisms. Thus, in considering socioeconomic and cultural perspectives of GE, it is important to bear in mind this diversity of strategies and applications: GE crops can differ markedly from one another.

All of the varied conventional breeding techniques in existence today will remain the keystone of sustainable crop improvement, for several reasons. First, GE is commonly not the best breeding approach. If conventional breeding techniques permit breeders to meet their breeding goals, then these will often be preferred. Second, even when a useful GE trait has been created, conventional breeding remains necessary in order to introgress the trait into elite breeding lines. Finally, in any given crop, a useful GE construct may target one or a few pathogens of particular importance, but other breeding techniques still may be important for tackling disease problems not targeted by available GE traits. Thus, GE should be understood, not as the best approach to addressing sustainability challenges, but merely as a suite of tools that capitalizes on the knowledge that biologists gain through our ongoing study of Nature. GE simply expands the breeding "toolbox," providing options to consider on a case-by-case basis for enhancing the sustainability of crop disease management.

Acknowledgments: Thanks to Aardra Kachroo (University of Kentucky), Wayne Parrott (University of Georgia), and the anonymous reviewers for providing helpful suggestions on a previous draft of this paper.

Conflicts of Interest: The author declares no conflict of interest in the topic of genetic engineering. For a detailed disclosure statement, see "Disclosure Statement on Industry Relations" at http:/ /out-of-thebox-vincelli.blogspot.com/2015/11/disclosure-statement-on-industry.html. All costs relating to the development of this review-routine academic expenses such as professorial salary, internet access, library services, etc. - were paid by the University of Kentucky. No external funding was solicited nor received for this project. Publication costs were waived by the journal

\section{References}

1. Pinstrup-Andersen, P. The future world food situation and the role of plant diseases. Plant Health Instr. 2001. [CrossRef]

2. Anway, M.D.; Leathers, C.; Skinner, M.K. Endocrine disruptor vinclozolin induced epigenetic transgenerational adult-onset disease. Endocrinology 2006, 147, 5515-5523. [CrossRef] [PubMed]

3. Taxvig, C.; Hass, U.; Axelstad, M.; Dalgaard, M.; Boberg, J.; Andeasen, H.R.; Vinggaard, A.M. Endocrinedisrupting activities in vivo of the fungicides tebuconazole and epoxiconazole. Toxicol. Sci. 2007, 100, 464-73. [CrossRef] [PubMed]

4. Pezzoli, G.; Cereda, E. Exposure to pesticides or solvents and risk of Parkinson disease. Neurology 2013, 80, 2035-2041. [CrossRef] [PubMed]

5. Beard, J.D.; Umbach, D.M.; Hoppin, J.A.; Richards, M.; Alavanja, M.C.; Blair, A.; Sandler, D.P.; Kamel, F. Pesticide exposure and depression among male private pesticide applicators in the agricultural health study. Environ. Health Perspect. 2014, 122, 984-991. [CrossRef] [PubMed]

6. Costello, S.; Cockburn, M.; Bronstein, J.; Zhang, X.; Ritz, B. Parkinson's disease and residential exposure to maneb and paraquat from agricultural applications in the Central Valley of California. Am. J. Epidemiol. 2009, 169, 919-926. [CrossRef] [PubMed] 
7. Collotta, M.; Bertazzi, P.A.; Bollati, V. Epigenetics and pesticides. Toxicology 2013, 307, 35-41. [CrossRef] [PubMed]

8. McMahon, T.A.; Halstead, N.T.; Johnson, S.; Raffel, T.R.; Romansic, J.M.; Crumrine, P.W.; Rohr, J.R. Fungicide-induced declines of freshwater biodiversity modify ecosystem functions and services. Ecol. Lett. 2012, 15, 714-722. [CrossRef] [PubMed]

9. Greitens, T.J.; Day, E. An alternative way to evaluate the environmental effects of integrated pest management: Pesticide risk indicators. Renew. Agric. Food Syst. 2007, 22, 213. [CrossRef]

10. Schafer, R.B.; Gerner, N.; Kefford, B.J.; Rasmussen, J.J.; Beketov, M.A.; de Zwart, D.; Liess, M.; von der Ohe, P.C. How to characterize chemical exposure to predict ecologic effects on aquatic communities? Environ. Sci. Technol. 2013, 47, 7996-8004. [CrossRef] [PubMed]

11. Malaj, E.; von der Ohe, P.C.; Grote, M.; Kuhne, R.; Mondy, C.P.; Usseglio-Polatera, P.; Brack, W.; Schafer, R.B. Organic chemicals jeopardize the health of freshwater ecosystems on the continental scale. Proc. Natl. Acad. Sci. USA 2014, 111, 9549-9554.

12. Zhu, Y.C.; Adamczyk, J.; Rinderer, T.; Yao, J.; Danka, R.; Luttrell, R.; Gore, J. Spray toxicity and risk potential of 42 commonly used formulations of row crop pesticides to adult honey bees (Hymenoptera: Apidae). J. Econ. Entomol. 2015, 108, 1-8.

13. Mader, E.; Adamson, N.L. Organic-Approved Pesticides: Minimizing Risks to Bees. Available online: http://www.xerces.org/wp-content/uploads/2009/12/xerces-organic-approved-pesticides-factsheet.pdf (accessed on 12 May 2016).

14. Barbosa, W.F.; De Meyer, L.; Guedes, R.N.C.; Smagghe, G. Lethal and sublethal effects of azadirachtin on the bumblebee Bombus terrestris (Hymenoptera: Apidae). Ecotoxicology 2015, 24, 130-142. [CrossRef] [PubMed]

15. Michaud, J.P.; Grant, A.K. Sub-lethal effects of a copper sulfate fungicide on development and reproduction in three coccinellid species. J. Insect. Sci. 2003, 3, 1-6. [CrossRef]

16. Hernández-Colorado, R.R.; Alvarado, A.L.; Romero, R.M. Acumulación de cobre en plantas silvestres de zonas agrícolas contaminadas con el metal. Cienc. Tecnol. 2012, 28, 55-61. (In Spanish)

17. Dutka, A.; McNulty, A.; Williamson, S.M. A new threat to bees? Entomopathogenic nematodes used in biological pest control cause rapid mortality in Bombus terrestris. Peer] 2015, 3, e1413. [CrossRef] [PubMed]

18. Cannon, J.R.; Tapias, V.M.; Na, H.M.; Honick, A.S.; Drolet, R.E.; Greenamyre, J.T. A highly reproducible rotenone model of Parkinson's disease. Neurobiol. Dis. 2009, 34, 279-290. [CrossRef] [PubMed]

19. Coats, J.R. Risks from natural versus synthetic insecticides. Annu. Rev. Entomol. 1994, 39, 489-515. [CrossRef] [PubMed]

20. Palti, J. Cultural Practices and Infectious Crop Diseases; Springer: Berlin, Germany, 1981; p. 246.

21. Ferreira, S.A.; Pitz, K.Y.; Manshardt, R.; Zee, F.; Fitch, M.; Gonsalves, D. Virus coat protein transgenic papaya provides practical control of papaya ringspot virus in Hawaii. Plant Dis. 2002, 86, 101-105. [CrossRef]

22. Taylor, N.J.; Halsey, M.; Gaitán-Solís, E.; Anderson, P.; Gichuki, S.; Miano, D.; Bua, A.; Alicai, T.; Fauquet, C.M. The VIRCA project: Virus resistant cassava for Africa. GM Crops Food 2012, 3, 93-103. [CrossRef] [PubMed]

23. Dutt, M.; Barthe, G.; Irey, M.; Grosser, J. Transgenic citrus expressing an Arabidopsis NPR1 gene exhibit enhanced resistance against huanglongbing (HLB; citrus greening). PLoS ONE 2015, 10, e0137134. [CrossRef] [PubMed]

24. Kress, R. Citrus Plants Resistant to Citrus Huanglongbing (ex greening) Caused by Candidatus Liberibacter Asiaticus (las) and Bacterial Canker Caused by (Xanthomonas axonopodis pv. citri) (xac). US20150067918 A1, 5 March 2015.

25. National Research Council. Strategic Planning for the Florida Citrus Industry: Addressing Citrus Greening Disease; The National Academies Press: Washington, DC, USA, 2010; p. 326.

26. Carpenter, J.E. Impact of GM crops on biodiversity. GM Crops 2011, 2, 7-23. [CrossRef] [PubMed]

27. Huang, J.; Rozelle, S.; Pray, C.; Wang, Q. Plant biotechnology in China. Science 2002, 295, 674-677. [CrossRef] [PubMed]

28. Huang, J.; Hu, R.; Qiao, F.; Yin, Y.; Liu, H.; Huang, Z. Impact of insect-resistant GM rice on pesticide use and farmers' health in China. Sci. China Life Sci. 2015, 58, 466-471. [CrossRef] [PubMed]

29. National Research Council. Impact of Genetically Engineered Crops on Farm Sustainability in the United States; The National Academies Press: Washington, DC, USA, 2010; p. 270.

30. Klumper, W.; Qaim, M. A meta-analysis of the impacts of genetically modified crops. PLoS ONE 2014, 9, e111629. [CrossRef] [PubMed] 
31. Kouser, S.; Qaim, M. Impact of Bt cotton on pesticide poisoning in smallholder agriculture: A panel data analysis. Ecol. Econ. 2011, 70, 2105-2113. [CrossRef]

32. Fernandez-Cornejo, J.; Wechsler, S.J.; Livingston, M.; Mitchell, L. Genetically Engineered Crops in the United States. Available online: www.ers.usda.gov/publications/err-economic-research-report/err162.aspx (accessed on 12 May 2016).

33. Huesing, J.; English, L. The impact of Bt crops on the developing world. AgBioForum 2004, 7, 84-95.

34. Zambrano, P.; Smale, M.; Maldonado, J.H.; Mendoza, S.L. Unweaving the threads: The experiences of female farmers with biotech cotton in Colombia. AgBioForum 2012, 15, 125-137.

35. Smyth, S.J.; Kerr, W.A.; Phillips, P.W.B. Global economic, environmental and health benefits from GM crop adoption. Glob. Food Secur. 2015, 7, 24-29. [CrossRef]

36. Gassmann, A.J.; Petzold-Maxwell, J.L.; Clifton, E.H.; Dunbar, M.W.; Hoffmann, A.M.; Ingber, D.A.; Keweshan, R.S. Field-evolved resistance by western corn rootworm to multiple Bacillus thuringiensis toxins in transgenic maize. Proc. Natl. Acad. Sci. USA 2014, 111, 5141-5146. [CrossRef] [PubMed]

37. Tabashnik, B.E.; Brevault, T.; Carriere, Y. Insect resistance to Bt crops: lessons from the first billion acres. Nat. Biotechnol. 2013, 31, 510-521. [CrossRef] [PubMed]

38. Huang, F.; Qureshi, J.A.; Meagher, R.L.Jr.; Reisig, D.D.; Head, G.P.; Andow, D.A.; Ni, X.; Kerns, D.; Buntin, G.D.; Niu, Y.; Yang, F.; Dangal, V. Cry1F resistance in fall armyworm Spodoptera frugiperda: Single gene versus pyramided Bt maize. PLoS ONE 2014, 9, e112958. [CrossRef] [PubMed]

39. Campagne, P.; Kruger, M.; Pasquet, R.; Le Ru, B.; Van den Berg, J. Dominant inheritance of field-evolved resistance to Bt corn in Busseola fusca. PLoS ONE 2013, 8, e69675.

40. Cochrane, G.; Karsch-Mizrachi, I.; Nakamura, Y. The international nucleotide sequence database collaboration. Nucleic Acids Res. 2011, 39, D15-D18. [CrossRef] [PubMed]

41. Chisholm, S.T.; Coaker, G.; Day, B.; Staskawicz, B.J. Host-microbe interactions: shaping the evolution of the plant immune response. Cell 2006, 124, 803-814. [CrossRef] [PubMed]

42. Jones, J.D.; Dangl, J.L. The plant immune system. Nature 2006, 444, 323-329. [CrossRef] [PubMed]

43. Jones, J.D.; Witek, K.; Verweij, W.; Jupe, F.; Cooke, D.; Dorling, S.; Tomlinson, L.; Smoker, M.; Perkins, S.; Foster, S. Elevating crop disease resistance with cloned genes. Philos. Trans. R. Soc. Lond. B. Biol. Sci. 2014, 369, 20130087. [CrossRef] [PubMed]

44. Lacombe, S.; Rougon-Cardoso, A.; Sherwood, E.; Peeters, N.; Dahlbeck, D.; van Esse, H.P.; Smoker, M.; Rallapalli, G.; Thomma, B.P.; Staskawicz, B.; et al. Interfamily transfer of a plant pattern-recognition receptor confers broad-spectrum bacterial resistance. Nat. Biotechnol. 2010, 28, 365-369. [CrossRef] [PubMed]

45. Tripathi, J.N.; Lorenzen, J.; Bahar, O.; Ronald, P.; Tripathi, L. Transgenic expression of the rice Xa21 pattern-recognition receptor in banana (Musa sp.) confers resistance to Xanthomonas campestris pv. musacearum. Plant Biotechnol. J. 2014, 12, 663-673. [CrossRef] [PubMed]

46. Schwessinger, B.; Bahar, O.; Thomas, N.; Holton, N.; Nekrasov, V.; Ruan, D.; Canlas, P.E.; Daudi, A.; Petzold, C.J.; Singan, V.R.; et al. Transgenic expression of the dicotyledonous pattern recognition receptor EFR in rice leads to ligand-dependent activation of defense responses. PLoS Pathog. 2015, 11, e1004809.

47. Dangl, J.L.; Horvath, D.M.; Staskawicz, B.J. Pivoting the plant immune system from dissection to deployment. Science 2013, 341, 746-751. [CrossRef] [PubMed]

48. Gill, U.S.; Lee, S.; Mysore, K.S. Host versus nonhost resistance: Distinct wars with similar arsenals. Phytopathology 2015, 105, 580-587. [CrossRef] [PubMed]

49. Stotz, H.U.; Mitrousia, G.K.; de Wit, P.J.; Fitt, B.D. Effector-triggered defence against apoplastic fungal pathogens. Trends Plant Sci. 2014, 19, 491-500. [CrossRef] [PubMed]

50. Saunders, D.G.O. Hitchhiker's guide to multi-dimensional plant pathology. N. Phytol. 2015, 205, 1028-1033. [CrossRef]

51. Holme, I.B.; Wendt, T.; Holm, P.B. Intragenesis and cisgenesis as alternatives to transgenic crop development. Plant Biotechnol. J. 2013, 11, 395-407. [CrossRef] [PubMed]

52. Jo, K.R.; Kim, C.J.; Kim, S.J.; Kim, T.Y.; Bergervoet, M.; Jongsma, M.A.; Visser, R.G.; Jacobsen, E.; Vossen, J.H. Development of Late Blight Resistant Potatoes by Cisgene Stacking. Available online: http:/ /www.biomedcentral.com/1472-6750/14/50 (accessed on 12 May 2016).

53. Tai, T.H.; Dahlbeck, D.; Clark, E.T.; Gajiwala, P.; Pasion, R.; Whalen, M.C.; Stall, R.E.; Staskawicz, B.J. Expression of the Bs2 pepper gene confers resistance to bacterial spot disease in tomato. Proc. Natl. Acad. Sci. USA 1999, 96, 14153-14158. [CrossRef] [PubMed] 
54. Horvath, D.M.; Stall, R.E.; Jones, J.B.; Pauly, M.H.; Vallad, G.E.; Dahlbeck, D.; Staskawicz, B.J.; Scott, J.W. Transgenic resistance confers effective field level control of bacterial spot disease in tomato. PLoS ONE 2012, 7, e42036. [CrossRef] [PubMed]

55. Yang, S.; Li, J.; Zhang, X.; Zhang, Q.; Huanga, J.; Chen, J.-Q.; Hart, D.L.; Tiana, D. Rapidly evolving R genes in diverse grass species confer resistance to rice blast disease. Proc. Natl. Acad. Sci. USA 2013, 110, 18572-18577. [CrossRef] [PubMed]

56. Kawashima, C.G.; Guimaraes, G.A.; Nogueira, S.R.; MacLean, D.; Cook, D.R.; Steuernagel, B.; Baek, J.; Bouyioukos, C.; Melo, B.D.; Tristao, G.; et al. A pigeonpea gene confers resistance to Asian soybean rust in soybean. Nat. Biotechnol. 2016. [CrossRef] [PubMed]

57. Kim, S.H.; Qi, D.; Ashfield, T.; Helm, M.; Innes, R.W. Using decoys to expand the recognition specificity of a plant disease resistance protein. Science 2016, 351, 684-687. [CrossRef] [PubMed]

58. Fukuoka, S.; Saka, N.; Mizukami, Y.; Koga, H.; Yamanouchi, U.; Yoshioka, Y.; Hayashi, N.; Ebana, K.; Mizobuchi, R.; Yano, M. Gene pyramiding enhances durable blast disease resistance in rice. Sci. Rep. 2015. [CrossRef] [PubMed]

59. Fry, W.E. Principles of Plant Disease Management; Academic Press: New York, NY, USA, 1982; p. 378.

60. Pel, M.A.; Foster, S.J.; Park, T.H.; Rietman, H.; van Arkel, G.; Jones, J.D.; Van Eck, H.J.; Jacobsen, E.; Visser, R.G.; Van der Vossen, E.A. Mapping and cloning of late blight resistance genes from Solanum venturii using an interspecific candidate gene approach. Mol. Plant Microbe Interact. 2009, 22, 601-615. [CrossRef] [PubMed]

61. Bundo, M.; Coca, M. Enhancing blast disease resistance by overexpression of the calcium-dependent protein kinase OsCPK4 in rice. Plant Biotechnol. J. 2015. [CrossRef]

62. Tripathi, L.; Tripathi, J.N.; Kiggundu, A.; Korie, S.; Shotkoski, F.; Tushemereirwe, W.K. Field trial of Xanthomonas wilt disease-resistant bananas in East Africa. Nat. Biotechnol. 2014, 32, 868-870. [CrossRef] [PubMed]

63. Ger, M.; Chen, C.; Hwang, S.; Huang, H.; Podile, A.R.; Dayakar, B.V.; Feng, T. Constitutive expression of hrap gene in transgenic tobacco plant enhances resistance against virulent bacterial pathogens by induction of a hypersensitive response. Mol. Plant-Microbe Interact. 2002, 15, 764-773. [CrossRef] [PubMed]

64. Huang, H.E.; Ger, M.J.; Yip, M.K.; Chen, C.Y.; Pandey, A.K.; Feng, T.Y. A hypersensitive response was induced by virulent bacteria in transgenic tobacco plants overexpressing a plant ferredoxin-like protein (PFLP). Physiol. Mol. Plant Pathol. 2004, 64, 103-110. [CrossRef]

65. Chen, X.J.; Chen, Y.; Zhang, L.N.; Xu, B.; Zhang, J.H.; Chen, Z.X.; Tong, Y.H.; Zuo, S.M.; Xu, J.Y. Overexpression of OsPGIP1 enhances rice resistance to sheath blight. Plant Dis. 2016, 100, 388-395. [CrossRef]

66. van Schie, C.C.; Takken, F.L. Susceptibility genes 101: How to be a good host. Annu. Rev. Phytopathol. 2014, 52, 551-581. [CrossRef] [PubMed]

67. Berg, J.A.; Appiano, M.; Santillan Martinez, M.; Hermans, F.W.; Vriezen, W.H.; Visser, R.G.; Bai, Y.; Schouten, H.J. A transposable element insertion in the susceptibility gene CsaMLO8 results in hypocotyl resistance to powdery mildew in cucumber. BMC Plant Biol. 2015, 15, 243. [CrossRef] [PubMed]

68. De Almeida Engler, J.; Favery, B.; Engler, G.; Abad, P. Loss of susceptibility as an alternative for nematode resistance. Curr. Opin. Biotechnol. 2005, 16, 112-117. [CrossRef] [PubMed]

69. Wang, Y.; Cheng, X.; Shan, Q.; Zhang, Y.; Liu, J.; Gao, C.; Qiu, J.L. Simultaneous editing of three homoeoalleles in hexaploid bread wheat confers heritable resistance to powdery mildew. Nat. Biotechnol. 2014, 32, 947-951. [CrossRef] [PubMed]

70. Jia, H.; Orbovic, V.; Jones, J.B.; Wang, N. Modification of the PthA4 effector binding elements in Type I CsLOB1 promoter using Cas9/sgRNA to produce transgenic Duncan grapefruit alleviating Xcc $\Delta$ pthA4:dCsLOB1.3 infection. Plant Biotechnol. J. 2016, 14, 1291-1301. [CrossRef] [PubMed]

71. Perez, M.G. Florida's Orange Industry Is in Its Worst Slump in 100 Years. Available online: http:/ / www.bloomberg.com/news/articles/2015-11-24/in-florida-the-oj-crop-is-getting-wipedout-by-an-asian-invader (accessed on 12 May 2016).

72. Harmon, A. A Race to Save the Orange by Altering Its DNA. Available online: http://www.nytimes.com/ 2013/07/28/science/a-race-to-save-the-orange-by-altering-its-dna.html?pagewanted=all\&_r=1 (accessed on 12 May 2016).

73. Ohlemeier, D. GMO Targets Citrus Greening. Available online: http://www.thepacker.com/news/floridagrower-growing-citrus-greening-resistant-gmo-fruit (accessed on 12 May 2016). 
74. Rubio, J.; Montes, C.; Castro, Á.; Álvarez, C.; Olmedo, B.; Muñoz, M.; Tapia, E.; Reyes, F.; Ortega, M.; Sánchez, E.; et al. Genetically engineered Thompson Seedless grapevine plants designed for fungal tolerance: Selection and characterization of the best performing individuals in a field trial. Transgenic Res. 2015, 24, 43-60. [CrossRef] [PubMed]

75. Emani, C.; Garcia, J.M.; Lopata-Finch, E.; Pozo, M.J.; Uribe, P.; Kim, D.J.; Sunilkumar, G.; Cook, D.R.; Kenerley, C.M.; Rathore, K.S. Enhanced fungal resistance in transgenic cotton expressing an endochitinase gene from Trichoderma virens. Plant Biotechnol. J. 2003, 1, 321-336. [CrossRef] [PubMed]

76. Bonning, B.C.; Pal, N.; Liu, S.; Wang, Z.; Sivakumar, S.; Dixon, P.M.; King, G.F.; Miller, W.A. Toxin delivery by the coat protein of an aphid-vectored plant virus provides plant resistance to aphids. Nat. Biotechnol. 2014, 32, 102-105. [CrossRef] [PubMed]

77. Badran, A.H.; Guzov, V.M.; Huai, Q.; Kemp, M.M.; Vishwanath, P.; Kain, W.; Nance, A.M.; Evdokimov, A.; Moshiri, F.; Turner, K.H.; et al. Continuous evolution of Bacillus thuringiensis toxins overcomes insect resistance. Nature 2016, 533, 58-63. [CrossRef] [PubMed]

78. Lusk, J.L.; Rozan, A. Consumer acceptance of ingenic foods. Biotechnol. J. 2006, 1, 1433-1434. [CrossRef] [PubMed]

79. Carthew, R.W.; Sontheimer, E.J. Origins and mechanisms of miRNAs and siRNAs. Cell 2009, 136, 642-655. [CrossRef] [PubMed]

80. Gonsalves, D.; Ferreira, S. Transgenic papaya: a case for managing risks of papaya ring spot virus in Hawaii. Plant Health Prog. 2003. [CrossRef]

81. Fitch, M.M.M.; Manschardt, R.M.; Gonsalves, D.; Slightom, J.L.; Sanford, J.C. Virus resistant papaya derived from tissues bombarded with the coat protein gene of papaya ringspot virus. Nat. Biotechnol. 1992, 10, 1466-1472. [CrossRef]

82. Odipio, J.; Ogwok, E.; Taylor, N.J.; Halsey, M.; Bua, A.; Fauquet, C.M.; Alicai, T. RNAi-derived field resistance to cassava brown streak disease persists across the vegetative cropping cycle. GM Crops Food 2014, 5, 16-19. [CrossRef] [PubMed]

83. Zhang, X.; Sato, S.; Ye, X.; Dorrance, A.E.; Morris, T.J.; Clemente, T.E.; Qu, F. Robust RNAi-based resistance to mixed infection of three viruses in soybean plants expressing separate short hairpins from a single transgene. Phytopathology 2011, 101, 1264-1269. [CrossRef] [PubMed]

84. Klas, F.E.; Fuchs, M.; Gonsalves, D. Fruit yield of virus-resistant transgenic summer squash in simulated commercial plantings under conditions of high disease pressure. J. Hortic. For. 2011, 3, 46-52.

85. Yang, C.F.; Chen, K.C.; Cheng, Y.H.; Raja, J.A.; Huang, Y.L.; Chien, W.C.; Yeh, S.D. Generation of marker-free transgenic plants concurrently resistant to a DNA geminivirus and a RNA tospovirus. Sci. Rep. 2014, 4, 5717. [PubMed]

86. Andrade, C.M.; Tinoco, M.L.P.; Rieth, A.F.; Maia, F.C.O.; Aragão, F.J.L. Host-induced gene silencing in the necrotrophic fungal pathogen Sclerotinia sclerotiorum. Plant Pathol. 2015, 65, 626-632. [CrossRef]

87. Nowara, D.; Gay, A.; Lacomme, C.; Shaw, J.; Ridout, C.; Douchkov, D.; Hensel, G.; Kumlehn, J.; Schweizer, P. HIGS: Host-induced gene silencing in the obligate biotrophic fungal pathogen Blumeria graminis. Plant Cell 2010, 22, 3130-3141. [CrossRef] [PubMed]

88. J.R. Simplot Company. Petition for Determination of Nonregulated Status for Innate ${ }^{\mathrm{TM}}$ Potatoes with Late Blight Resistance, Low Acrylamide Potential, Reduced Black Spot, and Lowered Reducing Sugars: Russet Burbank Event W8. Available online: https://www.aphis.usda.gov/brs/aphisdocs/14_09301p.pdf (accessed on 12 May 2016).

89. Jahan, S.N.; Asman, A.K.; Corcoran, P.; Fogelqvist, J.; Vetukuri, R.R.; Dixelius, C. Plant-mediated gene silencing restricts growth of the potato late blight pathogen Phytophthora infestans. J Exp. Bot. 2015, 66, 2785-2794. [CrossRef] [PubMed]

90. Krijger, J.J.; Oliveira-Garcia, E.; Astolfi, P.; Sommerfeld, K.; Gase, I.; Kastner, C.; Kumlehn, J.; Deising, H.B. Discovery of candidate genes for defeating fungal pathogens by host-induced gene silencing (HIGS). In Modern Fungicides and Antifungal Compounds VII; Dehne, H.W., Deising, B., Fraaije, U., Gisi, D., Hermann, D., Mehl, A., Oerke, E.C., Russell, P.E., Stammler, G., Kuck, K.H., Lyr, H., Eds.; Deutsche Phytomedizinische Gesellschaft: Braunschweig, Germany, 2014; pp. 35-44.

91. Govindarajulu, M.; Epstein, L.; Wroblewski, T.; Michelmore, R.W. Host-induced gene silencing inhibits the biotrophic pathogen causing downy mildew of lettuce. Plant Biotechnol. J. 2015, 13, 875-883. [CrossRef] [PubMed] 
92. Fan, W.; Wei, Z.; Zhang, M.; Ma, P.; Liu, G.; Zheng, J.; Guo, X.; Zhang, P. Resistance to Ditylenchus destructor infection in sweet potato by the expression of small interfering RNAs targeting unc-15, a movement-related gene. Phytopathology 2015, 105, 1458-1465. [CrossRef] [PubMed]

93. Lourenco-Tessutti, I.T.; Souza Junior, J.D.; Martins-de-Sa, D.; Viana, A.A.; Carneiro, R.M.; Togawa, R.C.; de Almeida-Engler, J.; Batista, J.A.; Silva, M.C.; Fragoso, R.R.; et al. Knock-down of heat-shock protein 90 and isocitrate lyase gene expression reduced root-knot nematode reproduction. Phytopathology 2015, 105, 628-637. [CrossRef] [PubMed]

94. Huang, G.; Allen, R.; Davis, E.L.; Baum, T.J.; Hussey, R.S. Engineering broad root-knot resistance in transgenic plants by RNAi silencing of a conserved and essential root-knot nematode parasitism gene. Proc. Natl. Acad. Sci. USA 2006, 103, 14302-14306. [CrossRef] [PubMed]

95. Noon, J.B.; Hewezi, T.; Maier, T.R.; Simmons, C.; Wei, J.Z.; Wu, G.; Llaca, V.; Deschamps, S.; Davis, E.L.; Mitchum, M.G.; Hussey, R.S.; Baum, T.J. Eighteen new candidate effectors of the phytonematode Heterodera glycines produced specifically in the secretory esophageal gland cells during parasitism. Phytopathology 2015, 105, 1362-1372. [CrossRef] [PubMed]

96. Baum, J.A.; Bogaert, T.; Clinton, W.; Heck, G.R.; Feldmann, P.; Ilagan, O.; Johnson, S.; Plaetinck, G.; Munyikwa, T.; Pleau, M.; et al. Control of coleopteran insect pests through RNA interference. Nat. Biotechnol. 2007, 25, 1322-1326. [CrossRef] [PubMed]

97. San Miguel, K.; Scott, J.G. The next generation of insecticides: dsRNA is stable as a foliar-applied insecticide. Pest Manag. Sci. 2015. [CrossRef] [PubMed]

98. Friesen, T.L.; Stukenbrock, E.H.; Liu, Z.; Meinhardt, S.; Ling, H.; Faris, J.D.; Rasmussen, J.B.; Solomon, P.S.; McDonald, B.A.; Oliver, R.P. Emergence of a new disease as a result of interspecific virulence gene transfer. Nat. Genet. 2006, 38, 953-956. [CrossRef] [PubMed]

99. Zhang, L.; Yao, J.; Withers, J.; Xin, X.F.; Banerjee, R.; Fariduddin, Q.; Nakamura, Y.; Nomura, K.; Howe, G.A.; Boland, W.; Yan, H.; He, S.Y. Host target modification as a strategy to counter pathogen hijacking of the jasmonate hormone receptor. Proc. Natl. Acad. Sci. USA 2015, 112, 14354-14359. [CrossRef] [PubMed]

100. Mobius, N.; Hertweck, C. Fungal phytotoxins as mediators of virulence. Curr. Opin. Plant Biol. 2009, 12, 390-398. [CrossRef] [PubMed]

101. Johal, G.S.; Briggs, S.P. Reductase activity encoded by the HM1 disease resistance gene in maize. Science 1992, 258, 985-987. [CrossRef] [PubMed]

102. Chen, C.; Sun, Q.; Narayanan, B.; Nuss, D.L.; Herzberg, O. Structure of oxalacetate acetylhydrolase, a virulence factor of the chestnut blight fungus. J. Biol. Chem. 2010, 285, 26685-26696. [CrossRef] [PubMed]

103. Zhang, B.; Oakes, A.D.; Newhouse, A.E.; Baier, K.M.; Maynard, C.A.; Powell, W.A. A threshold level of oxalate oxidase transgene expression reduces Cryphonectria parasitica-induced necrosis in a transgenic American chestnut (Castanea dentata) leaf bioassay. Transgenic Res. 2013, 22, 973-982. [CrossRef] [PubMed]

104. Li, X.; Shin, S.; Heinen, S.; Dill-Macky, R.; Berthiller, F.; Nersesian, N.; Clemente, T.; McCormick, S.; Muehlbauer, G.J. Transgenic wheat expressing a barley UDP-glucosyltransferase detoxifies deoxynivalenol and provides high levels of resistance to Fusarium graminearum. Mol. Plant Microbe Interact. 2015, 28, 1237-1246. [PubMed]

105. Shan, Q.; Wang, Y.; Li, J.; Zhang, Y.; Chen, K.; Liang, Z.; Zhang, K.; Liu, J.; Xi, J.J.; Qiu, J.L.; Gao, C. Targeted genome modification of crop plants using a CRISPR-Cas system. Nat. Biotechnol. 2013, 31, 686-688. [CrossRef] [PubMed]

106. Ali, Z.; Abulfaraj, A.; Idris, A.; Ali, S.; Tashkandi, M.; Mahfouz, M.M. CRISPR/Cas9-mediated viral interference in plants. Genome Biol. 2015, 16, 238. [CrossRef] [PubMed]

107. Ji, X.; Zhang, H.; Zhang, Y.; Wang, Y.; Gao, C. Establishing a CRISPR-Cas-like immune system conferring DNA virus resistance in plants. Nat. Plants 2015, 1, 15144. [CrossRef]

108. Chaparro-Garcia, A.; Kamoun, S.; Nekrasov, V. Boosting plant immunity with CRISPR/Cas. Genome Biol. 2015, 16, 254. [CrossRef] [PubMed]

109. Baltes, N.J.; Hummel, A.W.; Konecna, E.; Cegan, R.; Bruns, A.N.; Bisaro, D.M.; Voytas, D.F. Conferring resistance to geminiviruses with the CRISPR-Cas prokaryotic immune system. Nat. Plants 2015, 1, 15145. [CrossRef]

110. Rojas, M.R.; Hagen, C.; Lucas, W.J.; Gilbertson, R.L. Exploiting chinks in the plant's armor: evolution and emergence of geminiviruses. Annu. Rev. Phytopathol. 2005, 43, 361-394. [CrossRef] [PubMed] 
111. Clements, M.J.; Campbell, K.W.; Maragos, C.M.; Pilcher, C.; Headrick, J.M.; Pataky, J.K.; White, D.G. Influence of Cry1 Ab protein and hybrid genotype on fumonisin contamination and Fusarium ear rot of corn. Crop Sci. 2003, 43, 1283-1293. [CrossRef]

112. Folcher, L.; Delos, M.; Marengue, E.; Jarry, M.; Weissenberger, A.; Eychenne, N.; Regnault-Roger, C. Lower mycotoxin levels in Bt maize grain. Agron. Sustain. Dev. 2010, 30, 711-719. [CrossRef]

113. Munkvold, G.P.; Hellmich, R.L.; Rice, L.G. Comparison of fumonisin concentrations in kernels of transgenic Bt maize hybrids and nontransgenic hybrids. Plant Dis. 1999, 83, 130-138. [CrossRef]

114. Williams, W.P.; Windham, G.L.; Buckley, P.M.; Perkins, J.M. Southwestern corn borer damage and aflatoxin accumulation in conventional and transgenic corn hybrids. Field Crops Res. 2005, 91, 329-336. [CrossRef]

115. Williams, W.P.; Windham, G.L.; Buckley, P.M.; Daves, C.A. Aflatoxin accumulation in conventional and transgenic corn hybrids infested with southwestern corn borer (Lepidoptera: Crambidae). J. Agric. Urban Entomology 2002, 19, 227-236.

116. Munkvold, G.P.; Hellmich, R.L.; Showers, W.B. Reduced Fusarium ear rot and symptomless infection in kernels of maize genetically engineered for European corn borer resistance. Phytopathology 1997, 87, 1071-1077. [CrossRef] [PubMed]

117. Lamichhane, J.R.; Dachbrodt-Saaydeh, S.; Kudsk, P.; Messéan, A. Toward a reduced reliance on conventional pesticides in European agriculture. Plant Dis. 2016, 100, 10-24. [CrossRef]

118. Scheffer, R.P. The Nature of Disease in Plants; Cambridge University Press: New York, NY, USA, $1997 ;$ p. 325.

119. Burdon, J.J. Diseases and Plant Population Biology; Cambridge University Press: Cambridge, United Kingdom, 1997; p. 208.

120. Carriere, Y.; Crickmore, N.; Tabashnik, B.E. Optimizing pyramided transgenic Bt crops for sustainable pest management. Nat. Biotechnol. 2015, 33, 161-168. [CrossRef] [PubMed]

121. Zhu, S.; Li, Y.; Vossen, J.H.; Visser, R.G.; Jacobsen, E. Functional stacking of three resistance genes against Phytophthora infestans in potato. Transgenic Res. 2012, 21, 89-99. [CrossRef] [PubMed]

122. Singh, R.P.; Hodson, D.P.; Jin, Y.; Lagudah, E.S.; Ayliffe, M.A.; Bhavani, S.; Rouse, M.N.; Pretorius, Z.A.; Szabo, L.J.; Huerta-Espino, J.; Basnet, B.R.; Lan, C.; Hovmøller, M.S. Emergence and spread of new races of wheat stem rust fungus: Continued threat to food security and prospects of genetic control. Phytopathology 2015, 105, 872-884. [CrossRef] [PubMed]

123. Witek, K.; Jupe, F.; Witek, A.I.; Baker, D.; Clark, M.D.; Jones, J.D. Accelerated cloning of a potato late blight-resistance gene using RenSeq and SMRT sequencing. Nat. Biotechnol. 2016. [CrossRef] [PubMed]

124. Steuernagel, B.; Periyannan, S.K.; Hernandez-Pinzon, I.; Witek, K.; Rouse, M.N.; Yu, G.; Hatta, A.; Ayliffe, M.; Bariana, H.; Jones, J.D.; Lagudah, E.S.; Wulff, B.B. Rapid cloning of disease-resistance genes in plants using mutagenesis and sequence capture. Nat. Biotechnol. 2016. [CrossRef] [PubMed]

125. Yu, W.; Yau, Y.Y.; Birchler, J.A. Plant artificial chromosome technology and its potential application in genetic engineering. Plant Biotechnol. J. 2016, 14, 1175-1182. [CrossRef] [PubMed]

126. Marcroft, S.J.; Van de Wouw, A.P.; Salisbury, P.A.; Potter, T.D.; Howlett, B.J. Effect of rotation of canola (Brassica napus) cultivars with different complements of blackleg resistance genes on disease resistance. Plant Pathol. 2012, 61, 934-944. [CrossRef]

127. Zapiola, M.L.; Campbell, C.K.; Butler, M.D.; Mallory-Smith, C.A. Escape and establishment of transgenic glyphosate-resistant creeping bentgrass Agrostis stolonifera in Oregon, USA: A 4-year study. J. Appl. Ecol. 2008, 45, 486-494. [CrossRef]

128. Shivrain, V.K.; Burgos, N.R.; Anders, M.M.; Rajguru, S.N.; Moore, J.; Sales, M.A. Gene flow between Clearfield ${ }^{\mathrm{TM}}$ rice and red rice. Crop Prot. 2007, 26, 349-356. [CrossRef]

129. Fuchs, E.J.; Martínez, A.M.; Calvo, A.; Muñoz, M.; Arrieta-Espinoza, G. Genetic structure of Oryza glumaepatula wild rice populations and evidence of introgression from O. sativa in Costa Rica. PeerJ PrePrints 2015. [CrossRef]

130. Kwit, C.; Moon, H.S.; Warwick, S.I.; Stewart, C.N. Jr. Transgene introgression in crop relatives: molecular evidence and mitigation strategies. Trends Biotechnol. 2011, 29, 284-293. [CrossRef] [PubMed]

131. Kiang, Y.T.; Anotonovis, J.; Wu, L. The extinction of wild rice (Oryza perennis formosa) in Taiwan. J. Asian Ecol. 1979, 1, 1-9.

132. Sasu, M.A.; Ferrari, M.J.; Du, D.; Winsor, J.A.; Stephenson, A.G. Indirect costs of a nontarget pathogen mitigate the direct benefits of a virus-resistant transgene in wild Cucurbita. Proc. Natl. Acad. Sci. USA 2009, 106, 19067-19071. [CrossRef] [PubMed] 
133. Van Etten, L.; Kuester, A.; Chang, S.M.; Baucom, R. Reduced Seed Viability and Reductions in Plant Size Provide Evidence for Costs of Glyphosate Resistance in An Agricultural Weed. Available online: http:/ / biorxiv.org/content/early/2015/11/06/030833 (accessed on 19 May 2016).

134. Wang, W.; Xia, H.; Yang, X.; Xu, T.; Si, H.J.; Cai, X.X.; Wang, F.; Su, J.; Snow, A.A.; Lu, B.R. A novel 5-enolpyruvoylshikimate-3-phosphate (EPSP) synthase transgene for glyphosate resistance stimulates growth and fecundity in weedy rice (Oryza sativa) without herbicide. N. Phytol. 2014, 202, 679-688. [CrossRef] [PubMed]

135. Nielsen, K.M.; Johnsen, P.J.; Bensasson, D.; Daffonchio, D. Release and persistence of extracellular DNA in the environment. Environ. Biosaf. Res. 2007, 6, 37-53. [CrossRef] [PubMed]

136. Nielsen, K.M.; Bones, A.M.; Smalla, K.; van Elsas, J.D. Horizontal gene transfer from transgenic plants to terrestrial bacteria-a rare event? FEMS Microbiol. Rev. 1998, 22, 79-103. [CrossRef] [PubMed]

137. de Vries, J.; Wackernagel, W. Microbial horizontal gene transfer and the DNA release from transgenic crop plants. Plant Soil 2004, 266, 91-104. [CrossRef]

138. Syvanen, M. Search for horizontal gene transfer from transgenic crops to microbes. In Horizontal Gene Transfer; Syvanen, M., Kado, Cc.i., Eds.; Academic Press: London, UK, 2002; p. 445.

139. Demaneche, S.; Monier, J.M.; Dugat-Bony, E.; Simonet, P. Exploration of horizontal gene transfer between transplastomic tobacco and plant-associated bacteria. FEMS Microbiol. Ecol. 2011, 78, 129-136. [CrossRef] [PubMed]

140. Pontiroli, A.; Rizzi, A.; Simonet, P.; Daffonchio, D.; Vogel, T.M.; Monier, J.M. Visual evidence of horizontal gene transfer between plants and bacteria in the phytosphere of transplastomic tobacco. Appl. Environ Microbiol. 2009, 75, 3314-3322. [CrossRef] [PubMed]

141. Heinemann, J.A.; Traavik, T. Problems in monitoring horizontal gene transfer in field trials of transgenic plants. Nat. Biotechnol. 2004, 22, 1105-1109. [CrossRef] [PubMed]

142. Lu, B.R. Transgene escape from GM crops and potential biosafety consequences: An environmental perspective. Collect. Biosaf. Rev. 2008, 4, 66-141.

143. Baltazar, B.M.; Castro Espinoza, L.; Espinoza Banda, A.; de la Fuente Martinez, J.M.; Garzon Tiznado, J.A.; Gonzalez Garcia, J.; Gutierrez, M.A.; Guzman Rodriguez, J.L.; Heredia Diaz, O.; Horak, M.J.; et al. Pollen-mediated gene flow in maize: implications for isolation requirements and coexistence in Mexico, the center of origin of maize. PLoS ONE 2015, 10, e0131549. [CrossRef] [PubMed]

144. Gressel, J. Dealing with transgene flow of crop protection traits from crops to their relatives. Pest Manag. Sci. 2014, 71, 658-667. [CrossRef] [PubMed]

145. Gonzalez, M.D. Screening and Genotyping of Ga1 Gene and Genotype X Environment Interaction of Cross Incompatibility In Maize. Ph.D. Thesis, Iowa State University, Ames, IA, USA, 2011.

146. Lombardo, L. Genetic use restriction technologies: A review. Plant Biotechnol. J. 2014, 12, 995-1005. [CrossRef] [PubMed]

147. Li, J.; Yu, H.; Zhang, F.; Lin, C.; Gao, J.; Fang, J.; Ding, X.; Shen, Z.; Xu, X. A built-in strategy to mitigate transgene spreading from genetically modified corn. PLoS ONE 2013, 8, e81645. [CrossRef] [PubMed]

148. American Medical Association. Genetically Modified Crops and Foods. Available online: http://www.ilsi. org/NorthAmerica/Documents/AMA_2000InterimMeeting.pdf (accessed on 12 May 2016).

149. Committee on Identifying and Assessing Unintended Effects of Genetically Engineered Foods on Human Health; Food and Nutrition Board; Institute of Medicine; Board on Agriculture and Natural Resources; Board on Life Sciences; Division on Earth and Life Studies; National Research Council. Safety of Genetically Engineered Foods: Approaches to Assessing Unintended Health Effects; The National Academies Press: Washington, DC, USA, 2004; p. 256.

150. European Academies Science Advisory Council. Planting the Future: Opportunities and Challenges for Using Crop Genetic Improvement Technologies for Sustainable Agriculture. Available online: http://www.easac.eu/fileadmin/Reports/Planting_the_Future/EASAC_Planting_the_Future_ FULL_REPORT.pdf (accessed on 12 May 2016).

151. The Royal Society. Genetically Modified Plants for Food Use and Human Health—An Update. Available online: https://royalsociety.org/ \{\}/media/royal_society_content/policy/publications/2002/9960.pdf (accessed on 12 May 2016).

152. The Royal Society. Reaping the Benefits: Science and the Sustainable Intensification of Global Agriculture; Royal Society: Terrace, London, UK, 2009. 
153. Hollingworth, R.M.; Bjeldanes, L.F.; Bolger, M.; Kimber, I.; Meade, B.J.; Taylor, S.L.; Wallace, K.B. Society of Toxicology position paper: The safety of genetically modified foods produced through biotechnology. Toxicol. Sci. 2003, 71, 2-8.

154. American Association for the Advancement of Science. Statement by the AAAS Board of Directors on Labeling of Genetically Modified Foods. Available online: http://www.aaas.org/sites/default/files/AAAS_ GM_statement.pdf (accessed on 12 May 2016).

155. American Phytopathological Society Council. Compulsory Labeling of Plants and Plant Products Derived from Biotechnology. Available online: http://www.apsnet.org/members/outreach/ppb/ positionstatements/pages/biotechnologypositionstatement.aspx (accessed on 12 May 2016).

156. International Union of Nutritional Sciences. Statement on Benefits and Risks of Genetically Modified Foods for Human Health and Nutrition. Available online: http:/ / www.iuns.org/statement-on-benefits-and-risksof-genetically-modified-foods-for-human-health-and-nutrition/ (accessed on 12 May 2016).

157. American Medical Association. H-480.958 Bioengineered (Genetically Engineered) Crops and Foods. Available online: https://www.ama-assn.org/ssl3/ecomm/PolicyFinderForm.pl?site=www.ama-assn.org\& uri=/resources/html/PolicyFinder/policyfiles/HnE/H-480.958.HTM (accessed on 12 May 2016).

158. Board of Science and Education, Britsh Medical Association. Genetically Modified Foods and Health: A Second Interim Statement. Available online: http://www.argenbio.org/adc/uploads/pdf/bma.pdf (accessed on 12 May 2016).

159. Bruhn, C.; Earl, R.; American Dietetic Association. Position of the American dietetic association: Agricultural and food biotechnology. J. Am. Diet. Assoc. 2006, 106, 285-93. [PubMed]

160. Biochemical Society. Genetically Modified Crops, Feed and Food. Available online: http://www. biochemistry.org/Portals/0/SciencePolicy/Docs/GM\%20Position\%20Statement\%202011\%20Final.pdf (accessed on 12 May 2016).

161. Pramer, D. Statement of the American Society for Microbiology on Genetically Modified Organisms. Available online: http:/ /www.asm.org/index.php?option=com_content\&view=article\&id=3656\&Itemid= 341 (accessed on 12 May 2016).

162. Crop Science Society of America. Researchers and Farmers Utilize GM Technology to Address Society's Growing Global Food Production, Security, and Safety Needs. Available online: https://www.crops.org/ files/science-policy/issues/reports/cssa-gmo-statement.pdf (accessed on 12 May 2016).

163. Federation of Animal Science Societies. FASS Facts: On Biotech Crops - Impact on Meat, Milk and Eggs. Savoy, IL. Available online: http:/ / www.fass.org/geneticcrops.pdf (accessed on 12 May 2016).

164. Key, S.; Ma, J.K.; Drake, P.M. Genetically modified plants and human health. J. R. Soc. Med. 2008, 101, 290-298. [CrossRef] [PubMed]

165. Nicolia, A.; Manzo, A.; Veronesi, F.; Rosellini, D. An overview of the last 10 years of genetically engineered crop safety research. Crit. Rev. Biotechnol. 2014, 34, 77-88. [CrossRef] [PubMed]

166. European Commission. A Decade of EU-Funded GMO Research (2001-2010). Available online: https:/ /ec. europa.eu/research/biosociety/pdf/a_decade_of_eu-funded_gmo_research.pdf (accessed on 12 May 2016).

167. Van Eenennaam, A.L.; Young, A.E. Prevalence and impacts of genetically engineered feedstuffs on livestock populations. J. Anim. Sci. 2014, 92, 4255-4278. [CrossRef] [PubMed]

168. Delaney, B. Safety assessment of foods from genetically modified crops in countries with developing economies. Food Chem. Toxicol. 2015, 86, 132-143. [CrossRef] [PubMed]

169. Snell, C.; Bernheim, A.; Berge, J.B.; Kuntz, M.; Pascal, G.; Paris, A.; Ricroch, A.E. Assessment of the health impact of GM plant diets in long-term and multigenerational animal feeding trials: A literature review. Food Chem. Toxicol. 2012, 50, 1134-1148. [CrossRef] [PubMed]

170. Ricroch, A.E. Assessment of GE food safety using '-omics' techniques and long-term animal feeding studies. N. Biotechnol. 2013, 30, 349-354. [CrossRef] [PubMed]

171. Herman, R.A.; Price, W.D. Unintended compositional changes in genetically modified (GM) crops: 20 years of research. J. Agric. Food Chem. 2013, 61, 11695-11701. [CrossRef] [PubMed]

172. Committee on Genetically Modified Pest-Protected Plants; Board on Agriculture and Natural Resources; Division on Earth and Life Studies; National Research Council. Genetically Modified Pest-Protected Plants: Science and Regulation; The National Academies Press: Washington, DC, USA, 2000; p. 292.

173. Hartung, F.; Schiemann, J. Precise plant breeding using new genome editing techniques: opportunities, safety and regulation in the EU. Plant J. 2014, 78, 742-752. [CrossRef] [PubMed] 
174. Kolseth, A.K.; D’Hertefeldt, T.; Emmerich, M.; Forabosco, F.; Marklund, S.; Cheeke, T.E.; Hallin, S.; Weih, M. Influence of genetically modified organisms on agro-ecosystem processes. Agric. Ecosyst. Environ. 2015, 214, 96-106. [CrossRef]

175. Conko, G.; Kershen, D.L.; Miller, H.; Parrott, W.A. A risk-based approach to the regulation of genetically engineered organisms. Nat. Biotechnol. 2016, 34, 493-503. [CrossRef] [PubMed]

176. Diaz-Gomez, J.; Marin, S.; Capell, T.; Sanchis, V.; Ramos, A.J. The impact of Bacillus thuringiensis technology on the occurrence of fumonisins and other mycotoxins in maize. World Mycotoxin J. 2015. [CrossRef]

177. GMOs and Corn Mycotoxins. Available online: http://graincrops.blogspot.com/2013/08/gmos-and-cornmycotoxins.html (accessed on 12 May 2016).

178. Tarrio, R.; Ayala, F.J; Rodriguez-Trelles, F. The Vein Patterning 1 (VEP1) gene family laterally spread through an ecological network. PLoS ONE 2011, 6, e22279. [CrossRef] [PubMed]

179. Yang, Z.; Zhou, Y.; Huang, J.; Hu, Y.; Zhang, E.; Xie, Z.; Ma, S.; Gao, Y.; Song, S.; Xu, C.; Liang, G. Ancient horizontal transfer of transaldolase-like protein gene and its role in plant vascular development. N. Phytol. 2015, 206, 807-816. [CrossRef] [PubMed]

180. Emiliani, G.; Fondi, M.; Fani, R.; Gribaldo, S. A horizontal gene transfer at the origin of phenylpropanoid metabolism: A key adaptation of plants to land. Biol. Direct 2009, 4, 7. [CrossRef] [PubMed]

181. Kyndt, T.; Quispe, D.; Zhai, H.; Jarret, R.; Ghislain, M.; Liu, Q.; Gheysen, G.; Kreuze, J.F. The genome of cultivated sweet potato contains Agrobacterium T-DNAs with expressed genes: An example of a naturally transgenic food crop. Proc. Natl. Acad. Sci. USA 2015, 112, 5844-5849. [CrossRef] [PubMed]

182. Bock, R. The give-and-take of DNA: horizontal gene transfer in plants. Trends Plant Sci. 2010, 15, 11-22. [CrossRef] [PubMed]

183. Wang, Q.; Sun, H.; Huang, J. The evolution of land plants: a perspective from horizontal gene transfer. Acta Soc. Bot. Pol. 2014, 83, 363-368. [CrossRef]

184. El Baidouri, M.; Carpentier, M.C.; Cooke, R.; Gao, D.; Lasserre, E.; Llauro, C.; Mirouze, M.; Picault, N.; Jackson, S.A.; Panaud, O. Widespread and frequent horizontal transfers of transposable elements in plants. Genome Res. 2014, 24, 831-838. [CrossRef] [PubMed]

185. Fortune, P.M.; Roulin, A.; Panaud, O. Horizontal transfer of transposable elements in plants. Commun. Integr. Biol. 2008, 1, 74-77. [CrossRef] [PubMed]

186. Yue, J.; Hu, X.; Huang, J. Horizontal gene transfer in the innovation and adaptation of land plants. Plant Signal Behav. 2013, 8, e24130. [CrossRef] [PubMed]

187. Bergthorsson, U.; Richardson, A.O.; Young, G.J.; Goertzen, L.R.; Palmer, J.D. Massive horizontal transfer of mitochondrial genes from diverse land plant donors to the basal angiosperm Amborella. Proc. Natl. Acad. Sci. USA 2004, 101, 17747-17752. [CrossRef] [PubMed]

188. Geering, A.D.; Maumus, F.; Copetti, D.; Choisne, N.; Zwickl, D.J.; Zytnicki, M.; McTaggart, A.R.; Scalabrin, S.; Vezzulli, S.; Wing, R.A.; et al. Endogenous florendoviruses are major components of plant genomes and hallmarks of virus evolution. Nat. Commun. 2014, 5, 5269. [CrossRef] [PubMed]

189. Yang, Z.; Wang, Y.; Zhou, Y.; Gao, Q.; Zhang, E.; Zhu, L.; Hu, Y.; Xu, C. Evolution of land plant genes encoding L-Ala-D/L-Glu epimerases (AEEs) via horizontal gene transfer and positive selection. BMC Plant Biol. 2013, 13, 34. [CrossRef] [PubMed]

190. Matveeva, T.V.; Lutova, L.A. Horizontal gene transfer from Agrobacterium to plants. Front. Plant Sci. 2014, 5, 326. [CrossRef] [PubMed]

191. Huang, J.; Yue, J. Horizontal gene transfer in the evolution of photosynthetic eukaryotes. J. Syst. Evol. 2013, 51, 13-29. [CrossRef]

192. Diao, X.; Freeling, M.; Lisch, D. Horizontal transfer of a plant transposon. PLoS Biol. 2005. [CrossRef] [PubMed]

193. Stegemann, S.; Keuthe, M.; Greiner, S.; Bock, R. Horizontal transfer of chloroplast genomes between plant species. PNAS 2012, 109, 2434-2438. [CrossRef] [PubMed]

194. Markova, D.N.; Mason-Gamer, R.J. The role of vertical and horizontal transfer in the evolutionary dynamics of PIF-like transposable elements in Triticeae. PLoS ONE 2015, 10, e0137648. [CrossRef] [PubMed]

195. Schnell, J.; Steele, M.; Bean, J.; Neuspiel, M.; Girard, C.; Dormann, N.; Pearson, C.; Savoie, A.; Bourbonniere, L.; Macdonald, P. A comparative analysis of insertional effects in genetically engineered plants: Considerations for pre-market assessments. Transgenic Res. 2015, 24, 1-17. [CrossRef] [PubMed] 
196. Gao, L.; Cao, Y.; Xia, Z.; Jiang, G.; Liu, G.; Zhang, W.; Zhai, W. Do transgenesis and marker-assisted backcross breeding produce substantially equivalent plants? A comparative study of transgenic and backcross rice carrying bacterial blight resistant gene Xa21. BMC Genom. 2013, 14, 738. [PubMed]

197. Batista, R.; Saibo, N.; Lourenco, T.; Oliveira, M.M. Microarray analyses reveal that plant mutagenesis may induce more transcriptomic changes than transgene insertion. Proc. Natl. Acad. Sci. USA 2008, 105, 3640-3645. [CrossRef] [PubMed]

198. Lehesranta, S.J.; Davies, H.V.; Shepherd, L.V.; Nunan, N.; McNicol, J.W.; Auriola, S.; Koistinen, K.M.; Suomalainen, S.; Kokko, H.I.; Karenlampi, S.O. Comparison of tuber proteomes of potato varieties, landraces, and genetically modified lines. Plant Physiol. 2005, 138, 1690-1699. [CrossRef] [PubMed]

199. Ladics, G.S.; Bartholomaeus, A.; Bregitzer, P.; Doerrer, N.G.; Gray, A.; Holzhauser, T.; Jordan, M.; Keese, P.; Kok, E.; Macdonald, P.; Parrott, W.; Privalle, L.; Raybould, A.; Rhee, S.Y.; Rice, E.; Romeis, J.; Vaughn, J.; Wal, J.M.; Glenn, K. Genetic basis and detection of unintended effects in genetically modified crop plants. Transgenic Res. 2015, 24, 587-603. [CrossRef] [PubMed]

200. El Ouakfaoui, S.; Miki, B. The stability of the Arabidopsis transcriptome in transgenic plants expressing the marker genes nptII and uidA. Plant J. 2005, 41, 791-800. [CrossRef] [PubMed]

201. Kok, E.J.; Keijer, J.; Kleter, G.A.; Kuiper, H.A. Comparative safety assessment of plant-derived foods. Regul. Toxicol. Pharmacol. 2008, 50, 98-113. [CrossRef] [PubMed]

202. Shi, G.; Chavas, J.P.; Lauer, J.; Nolan, E. An analysis of selectivity in the productivity evaluation of biotechnology: an application to corn. Am. J. Agric. Econ. 2013, 95, 739-754. [CrossRef]

203. Howard, P.H. Visualizing consolidation in the global seed industry: 1996-2008. Sustainability 2009, 1, 1266-1287. [CrossRef]

204. Heinemann, J.A.; Massaro, M.; Coray, D.S.; Agapito-Tenfen, Z.F.; Wen, J.D. Sustainability and innovation in staple crop production in the US Midwest. Int. J. Agric. Sustain. 2014, 12, 71-88. [CrossRef]

205. Stein, H. Intellectual property and genetically modified seeds: The United States, trade, and the developing world. Northwest. J. Technol. Intell. Prop. 2005, 3, 160-178.

206. Mascarenhas, M.; Busch, L. Seeds of change: intellectual property rights, genetically modified soybeans and seed saving in the United States. Eur. Soc. R. Soc. 2006, 46, 122-138. [CrossRef]

207. McGuire, S.; Sperling, L. Seed systems smallholder farmers use. Food Security 2016, 8, 179-195. [CrossRef]

208. Eisenstein, M. Biotechnology: Against the grain. Nature 2014, 514, S55-S57. [CrossRef] [PubMed]

209. What is C4 Rice? Available online:. Available online: http://c4rice.irri.org/index.php/component/content/ article/19-about/56-what-is-c4-rice (accessed on 12 May 2016).

210. Sneller, C.H. Impact of transgenic genotypes and subdivision on diversity within elite North American soybean germplasm. Crop Sci. 2003, 43, 409-414. [CrossRef]

211. Biddle, J.B. Can patents prohibit research? On the social epistemology of patenting and licensing in science. Stud. Hist. Philos. Sci. Part A 2014, 45, 14-23. [CrossRef]

212. Plant vs. Utility Patents. Available online: http://perennialpatents.com/plantpatent-v-utility-patents/ (accessed on 12 May 2016).

213. Hamilton, L.M. Linux for Lettuce. Available online: http://www.vqronline.org/reporting-articles/2014/05/ linux-lettuce (accessed on 12 May 2016).

214. Glenna, L.L.; Tooker, J.; Welsh, J.R.; Ervin, D. Intellectual property, scientific independence, and the efficacy and environmental impacts of genetically engineered crops. Rural Sociol. 2015, 80, 147-172. [CrossRef]

215. Prado, J.R.; Segers, G.; Voelker, T.; Carson, D.; Dobert, R.; Phillips, J.; Cook, K.; Cornejo, C.; Monken, J.; Grapes, L.; Reynolds, T.; Martino-Catt, S. Genetically engineered crops: From idea to product. Annu. Rev. Plant Biol. 2014, 65, 769-790. [CrossRef] [PubMed]

216. Open Source Seed Initiative. Available online: http://osseeds.org/about/ (accessed on 12 May 2016).

217. Krishna, V.; Qaim, M.; Zilberman, D. Transgenic crops, production risk and agrobiodiversity. Eur. Rev. Agric. Econ. 2015, 1-28.

218. Sander, J.D.; Joung, J.K. CRISPR-Cas systems for editing, regulating and targeting genomes. Nat. Biotechnol. 2014, 32, 347-355. [CrossRef] [PubMed]

219. Belhaj, K.; Chaparro-Garcia, A.; Kamoun, S.; Nekrasov, V. Plant genome editing made easy: targeted mutagenesis in model and crop plants using the CRISPR/Cas system. Plant Methods 2013, 9, 39. [CrossRef] [PubMed] 
220. Doudna, J.A.; Charpentier, E. The new frontier of genome engineering with CRISPR-Cas9. Science 2014, 346, 1258096. [CrossRef] [PubMed]

221. Woo, J.W.; Kim, J.; Kwon, S.I.; Corvalan, C.; Cho, S.W.; Kim, H.; Kim, S.G.; Kim, S.T.; Choe, S.; Kim, J.S. DNA-free genome editing in plants with preassembled CRISPR-Cas9 ribonucleoproteins. Nat. Biotechnol. 2015, 33, 1162-1164. [CrossRef] [PubMed]

222. Hallerman, E.; Grabau, E. Crop biotechnology: A pivotal moment for global acceptance. Food Energy Secur. 2016, 5, 3-17. [CrossRef]

223. Voytas, D.F.; Gao, C. Precision genome engineering and agriculture: opportunities and regulatory challenges. PLoS Biol. 2014, 12, e1001877. [CrossRef] [PubMed]

224. Huang, S.; Weigel, D.; Beachy, R.N.; Li, J. A proposed regulatory framework for genome-edited crops. Nat. Genet. 2016, 48, 109-111. [CrossRef] [PubMed]

225. Schiemann, J.; Hartung, F. EU perspectives on new plant-breeding techniques. In New DNA-Editing Approaches: Methods, Applications and Policy for Agriculture; Eaglesham, A., Hardy, R.W.F., Eds.; North American Agricultural Biotechnology Council: Ithaca, NY, USA, 2015; p. 276.

226. Li, K.; Wang, G.; Andersen, T.; Zhou, P.; Pu, W.T. Optimization of genome engineering approaches with the CRISPR/Cas9 system. PLoS ONE 2014, 9, e105779. [CrossRef] [PubMed]

227. Gaj, T.; Gersbach, C.A.; Barbas, C.F., III. ZFN, TALEN, and CRISPR/Cas-based methods for genome engineering. Trends Biotechnol. 2013, 31,397-405. [PubMed]

(C) 2016 by the author; licensee MDPI, Basel, Switzerland. This article is an open access article distributed under the terms and conditions of the Creative Commons Attribution (CC-BY) license (http://creativecommons.org/licenses/by/4.0/). 